\title{
Characterisation of large zooplankton sampled with two different gears during midwinter in Rijpfjorden, Svalbard
}

\author{
Katarzyna BŁACHOWIAK-SAMOŁ YK ${ }^{1 *}$, Adrian ZWOLICKI ${ }^{2}$, Clare N. WEBSTER ${ }^{3}$, \\ Rafał BOEHNKE ${ }^{1}$, Marcin WICHOROWSKI ${ }^{1}$, Anette WOLD ${ }^{4}$ and Luiza BIELECKA ${ }^{5}$ \\ ${ }^{1}$ Institute of Oceanology Polish Academy of Sciences, \\ Powstańców Warszawy 55, 81-712 Sopot, Poland \\ 2 University of Gdansk, Department of Vertebrate Ecology and Zoology, \\ Wita Stwosza 59, 80-308 Gdańsk, Poland \\ ${ }^{3}$ Pelagic Ecology Research Group, Scottish Oceans Institute, University of St Andrews, \\ KY16 8LB, St Andrews, UK \\ ${ }^{4}$ Norwegian Polar Institute, Framsenteret, 9296 Troms $\phi$, Norway \\ ${ }^{5}$ Department of Marine Ecosystems Functioning, Faculty of Oceanography and Geography, \\ Institute of Oceanography, University of Gdańsk, Al. Marszatka Pitsudskiego 46, \\ 81-378 Gdynia, Poland \\ *corresponding author<kasiab@iopan.gda.pl>
}

\begin{abstract}
During a midwinter cruise north of $80^{\circ} \mathrm{N}$ to Rijpfjorden, Svalbard, the composition and vertical distribution of the zooplankton community were studied using two different samplers 1) a vertically hauled multiple plankton sampler (MPS; mouth area $0.25 \mathrm{~m}^{2}$, mesh size $200 \mu \mathrm{m}$ ) and 2) a horizontally towed Methot Isaacs Kidd trawl (MIK; mouth area $3.14 \mathrm{~m}^{2}$, mesh size $1500 \mu \mathrm{m}$ ). Our results revealed substantially higher species diversity (49 taxa) than if a single sampler (MPS: 38 taxa, MIK: 28) had been used. The youngest stage present (CIII) of Calanus spp. (including C. finmarchicus and C. glacialis) was sampled exclusively by the MPS, and the frequency of CIV copepodites in MPS was double that than in MIK samples. In contrast, catches of the CV-CVI copepodites of Calanus spp. were substantially higher in the MIK samples (3-fold and 5-fold higher for adult males and females, respectively). The MIK sampling clearly showed that the highest abundances of all three Thysanoessa spp. were in the upper layers, although there was a tendency for the larger-sized euphausiids to occur deeper. Consistent patterns for the vertical distributions of the large zooplankters (e.g. ctenophores, euphausiids) collected by the MPS and MIK samplers provided more complete data on their abundances and sizes than obtained by the single net. Possible
\end{abstract}


mechanisms contributing to the observed patterns of distribution, e.g. high abundances of both Calanus spp. and their predators (ctenophores and chaetognaths) in the upper water layers during midwinter are discussed.

Key words: Arctic, Rijpfjorden, zooplankton, vertical distribution patterns, abundance and size, polar night.

\section{Introduction}

In pelagic ecosystems zooplankton is the key link between primary producers and the higher trophic levels. Zooplankters play an integral role in the recycling of nutrients and dissolved organic matter within the water column. Zooplankton is normally patchily distributed across a broad range of horizontal spatial scales from the micro scales $(<10 \mathrm{~m})$ of copepod patches (e.g. Trudnowska et al. 2016) to much larger scales as seen in some of the dense swarms (10 $\mathrm{m}$ to $1 \mathrm{~km}$ ) of euphausiids (Folt and Burns 1999; Lough and Broughton 2007). Vertical distributions are also finely structured and the need to quantify these 3-D patterns has encouraged development of sampling gears that can properly quantify zooplankton abundance and community structure (Wiebe et al. 2002). The development of multiple net sampling systems, designed to discriminate discrete depth strata, has improved the precision with which we can determine the abundance and depth distribution of zooplankton (see review by Wiebe and Benfield 2003). The choice of mesh size and net type is a basic consideration with regard to achieving appropriate sampling efficiency (Pearcy et al. 1983). Many studies (e.g., Vannucci 1968; Antacli et al. 2010 and citations therein) have shown that no single net system or mesh size can adequately sample the complete spectrum of plankton sizes. In order to achieve more representative estimates of abundance across a broader range of size spectrum of zooplankton, a combination of different nets needs to be used and the size-related sampling efficiency of each net taken into account when analysing and interpreting the data.

Using only standard mesozooplankton gear such as MPS or WP2 nets leads to substantial underestimation of both tiny specimens (Gallienne and Robins 2001; Hopcroft et al. 2005) as well as the larger zooplankters (e.g. Vinogradov 1997; Sameoto et al. 2000). The key factors that affect the precision of samples include: diel vertical migration, sensory perception by the target species (noise, vision, pressure wakes), swimming capabilities of young versus mature individuals, and their feeding behaviours (Johnson and Fogarty 2013). For example, avoidance and detection of nets disproportionally affects abundance estimates of the larger and faster swimming zooplankters, which cannot only be a numerically significant part of the community, but also occupying key positions in food webs (e.g. carnivores that are sparsely distributed). The problem is even more acute when 
trying to estimate most ctenophores and siphonophores because they are almost impossible to be sampled quantitatively. Predators are expected to occur in lower abundances than their prey, and often not only are their distributions patchy, both vertically and horizontally (Swanberg and Båmstedt 1991). Moreover, the problem of trying to comprehend three-dimensional distributions with the fourth dimension of time with a one-dimensional linear sampling is yet to be resolved but using arrays of samplers with different characteristics can improve our insights.

In this study we present data collected during a cruise to the ice free area north of $80^{\circ} \mathrm{N}$ in January 2012, which aimed to describe the differences in species composition, vertical distributions and size spectra of the zooplankton communities sampled using two different gears; 1 ) a vertically hauled multiple plankton sampler (MPS) with a mouth area of $0.25 \mathrm{~m}^{2}$ and mesh size of $200 \mu \mathrm{m}$ and 2) a horizontally towed modified Methot Isaacs Kidd trawl (MIK) with a mouth area of $3.14 \mathrm{~m}^{2}$ and mesh size of $1500 \mu \mathrm{m}$. Although there have been a few recent investigations of the mesozooplankton communities in the European Arctic during wintertime (e.g. Daase et al. 2014; Grigor et al. 2014; Båtnes et al. 2015; Błachowiak-Samołyk et al. 2015; Lischka and Hagen 2016) and some macrozooplankton (e.g., Søreide et al. 2003; Zhukova et al. 2009; Webster et al . 2015; Grenvald et al. 2016; Bandara et al. 2016) more comprehensive data on a broader spectrum of zooplankton size fractions is needed if our current level of understanding continues to be based solely on data for the more abundant and readily sampled size fractions (e.g. mesozooplankton).

The aims of this paper are threefold: 1) to describe differences in the diversity, vertical distributions and sizes of the zooplankton derived from two different nets; 2) to demonstrate the effectiveness of the two gears (MPS and MIK) in sampling Calanus population, and 3) to contribute to expand our poor knowledge of large zooplankters such as euphausiids, gelatinous organisms and chaetognaths, which generally occur at relatively low densities.

\section{Material and methods}

Study area. - This study was a component of the Polar Night Cruise conducted in January 2012 by R/V Helmer Hanssen in Rijpfjorden, an Arctic fjord on the most northern island of Spitsbergen, Nordaustlandet (Fig. 1). The multiple plankton sampler (MPS) samples were collected on 12 January 2012 at an inner station (MPS $1,80^{\circ} 18.51 \mathrm{~N}, 22^{\circ} 15.70 \mathrm{E}$ ) and on 13 January 2012 at an outer Rijpfjorden station (MPS 2, 80 $18.75 \mathrm{~N}, 22^{\circ} 15.98 \mathrm{E}$ ), $\sim 30 \mathrm{~km}$ apart. The MIK samples were collected near the outer MPS 2 station (Fig. 1; Tables 1 and 2). Rijpfjorden is a north-facing fjord (max. $270 \mathrm{~m}$ deep), with a wide opening towards the broad shallow shelf (100-200 m deep), connecting 


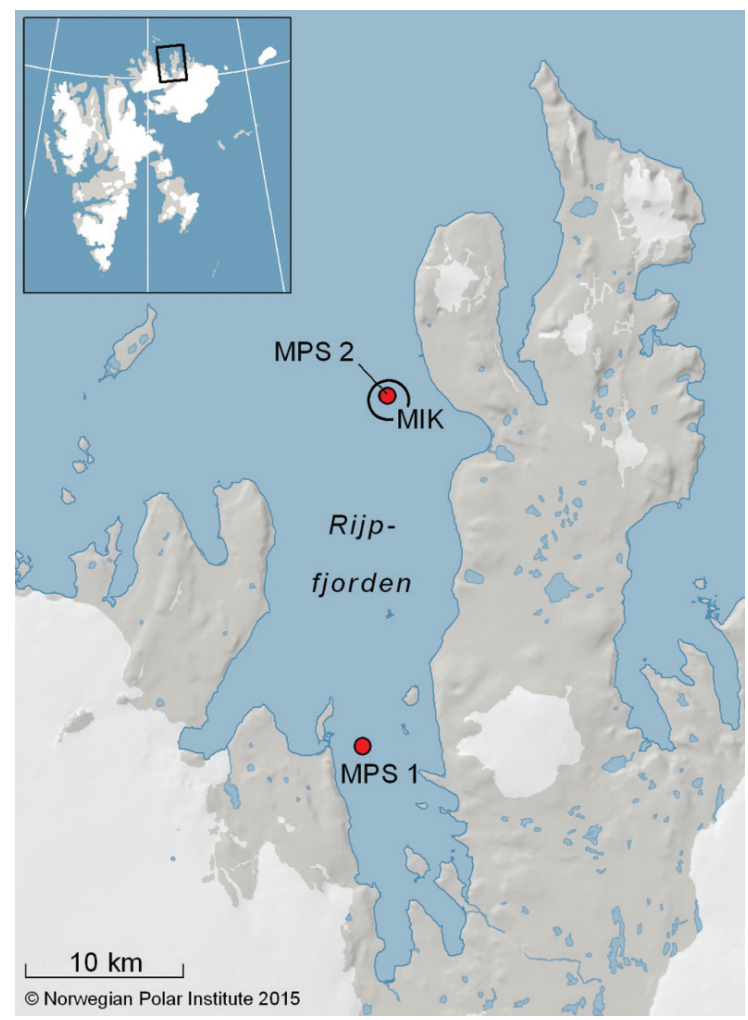

Fig. 1. Sampling region in northern Svalbard waters. MPS 1 (inner) and MPS 2 (outer) stations marked as red dots. MIK sampling site was marked as a circle near MPS 2 station.

it to the Arctic Ocean. Generally the hydrography of the fjord is dominated by cold Arctic water masses, since inflows of Atlantic water are far less pronounced than into the fjords along the western coast of Spitsbergen. Since the advection of relatively warm Atlantic water into the fjord during the ice-covered period is so limited, the zooplankton community is dominated by Arctic species (Falk-Petersen et al. 2008). However, episodic inflows of Atlantic water may occur from the West Spitsbergen Current during the ice-free period in autumn, which may introduce zooplankton and fish of Atlantic origin into the fjord. In January 2012 the waters of Rijpfjorden were homogenous with cold and a low salinity waters at the surface, separated from the deeper, slightly warmer water by a sharp pycnocline at $60-70 \mathrm{~m}$ depth (Falk-Petersen et al. 2014). The fjord was ice free, except the fast ice from land that was in the inner part of the fjord. 
Table 1

Overview of Multinet (MPS) zooplankton samples taken from standard depth layers (0-20-50-100-200-260 m) from the R/V Helmer Hanssen from two stations inner (MPS 1) during midday and outer (MPS 2) during midnight situated in Rijpfjorden (see Fig. 1 for details) during the Polar Night Cruise of January 2012.

\begin{tabular}{|c|c|c|c|c|c|}
\hline MPS & Date & Time (UTC) & Depth layer $(\mathrm{m})$ & Latitude & Longitude \\
\hline MPS 1_1 & 12.01 .2012 & $13: 10$ & $260-200$ & $80^{\circ} 18.51 \mathrm{~N}$ & $22^{\circ} 15.70 \mathrm{E}$ \\
\hline MPS 1_2 & 12.01 .2012 & $13: 10$ & $200-100$ & $80^{\circ} 18.51 \mathrm{~N}$ & $22^{\circ} 15.70 \mathrm{E}$ \\
\hline MPS 1_3 & 12.01 .2012 & $13: 10$ & $100-50$ & $80^{\circ} 18.51 \mathrm{~N}$ & $22^{\circ} 15.70 \mathrm{E}$ \\
\hline MPS 1_4 & 12.01 .2012 & $13: 10$ & $50-20$ & $80^{\circ} 18.51 \mathrm{~N}$ & $22^{\circ} 15.70 \mathrm{E}$ \\
\hline MPS 1_5 & 12.01 .2012 & $13: 10$ & $20-0$ & $80^{\circ} 18.51 \mathrm{~N}$ & $22^{\circ} 15.70 \mathrm{E}$ \\
\hline MPS 2_1 & 13.01 .2012 & $01: 05$ & $260-200$ & $80^{\circ} 18.75 \mathrm{~N}$ & $22^{\circ} 15.98 \mathrm{E}$ \\
\hline MPS 2_2 & 13.01 .2012 & $01: 05$ & $200-100$ & $80^{\circ} 18.75 \mathrm{~N}$ & $22^{\circ} 15.98 \mathrm{E}$ \\
\hline MPS 2_3 & 13.01 .2012 & $01: 05$ & $100-50$ & $80^{\circ} 18.75 \mathrm{~N}$ & $22^{\circ} 15.98 \mathrm{E}$ \\
\hline MPS 2_4 & 13.01 .2012 & $01: 05$ & $50-20$ & $80^{\circ} 18.75 \mathrm{~N}$ & $22^{\circ} 15.98 \mathrm{E}$ \\
\hline MPS 2_5 & 13.01 .2012 & $01: 05$ & $20-0$ & $80^{\circ} 18.75 \mathrm{~N}$ & $22^{\circ} 15.98 \mathrm{E}$ \\
\hline
\end{tabular}

Table 2

Overview of MIK nets horizontally towed at standard depth layers

(20, 75 and $225 \mathrm{~m})$ from the R/V Helmer Hanssen in Rijpfjorden

(see Fig. 1 for details) during the Polar Night Cruise of January 2012.

\begin{tabular}{|c|c|c|c|c|c|c|}
\hline MIK & Date & Time (UTC) & Depth (m) & & Latitude & Longitude \\
\hline \multirow{2}{*}{ MIK 1} & \multirow{2}{*}{12.01 .2012} & \multirow{2}{*}{$11: 46$} & \multirow{2}{*}{75} & Start & $80^{\circ} 19.09 \mathrm{~N}$ & $22^{\circ} 11.39 \mathrm{E}$ \\
\hline & & & & End & $80^{\circ} 19.17 \mathrm{~N}$ & $22^{\circ} 11.45 \mathrm{E}$ \\
\hline \multirow{2}{*}{ MIK 2} & \multirow{2}{*}{12.01 .2012} & \multirow{2}{*}{$12: 22$} & \multirow{2}{*}{225} & Start & $80^{\circ} 18.86 \mathrm{~N}$ & $22^{\circ} 14.75 \mathrm{E}$ \\
\hline & & & & End & $80^{\circ} 18.59 \mathrm{~N}$ & $22^{\circ} 16.14 \mathrm{E}$ \\
\hline \multirow{2}{*}{ MIK 3} & \multirow{2}{*}{ 13.01.2012 } & \multirow{2}{*}{$23: 53$} & \multirow{2}{*}{20} & Start & $80^{\circ} 18.51 \mathrm{~N}$ & $22^{\circ} 15.96 \mathrm{E}$ \\
\hline & & & & End & $80^{\circ} 18.73 \mathrm{~N}$ & $22^{\circ} 18.13 \mathrm{E}$ \\
\hline \multirow{2}{*}{ MIK 4} & \multirow{2}{*}{13.01 .2012} & \multirow{2}{*}{ 00:29 } & \multirow{2}{*}{75} & Start & $80^{\circ} 18.76 \mathrm{~N}$ & $22^{\circ} 15.99 \mathrm{E}$ \\
\hline & & & & End & $80^{\circ} 19.27 \mathrm{~N}$ & $22^{\circ} 15.08 \mathrm{E}$ \\
\hline \multirow{2}{*}{ MIK 5} & \multirow{2}{*}{13.01 .2012} & \multirow{2}{*}{$11: 04$} & \multirow{2}{*}{20} & Start & $80^{\circ} 18.79 \mathrm{~N}$ & $22^{\circ} 14.4 \mathrm{E}$ \\
\hline & & & & End & $80^{\circ} 19.10 \mathrm{~N}$ & $22^{\circ} 14.46 \mathrm{E}$ \\
\hline \multirow{2}{*}{ MIK 6} & \multirow{2}{*}{13.01 .2012} & \multirow{2}{*}{$11: 36$} & \multirow{2}{*}{75} & Start & $80^{\circ} 19.10 \mathrm{~N}$ & $22^{\circ} 14.48 \mathrm{E}$ \\
\hline & & & & End & $80^{\circ} 19.10 \mathrm{~N}$ & $22^{\circ} 17.01 \mathrm{E}$ \\
\hline \multirow{2}{*}{ MIK 7} & \multirow{2}{*}{13.01 .2012} & \multirow{2}{*}{$12: 18$} & \multirow{2}{*}{225} & Start & $80^{\circ} 18.61 \mathrm{~N}$ & $22^{\circ} 15.36 \mathrm{E}$ \\
\hline & & & & End & $80^{\circ} 18.24 \mathrm{~N}$ & $22^{\circ} 14.69 \mathrm{E}$ \\
\hline
\end{tabular}


Net sampling. - MPS sampling was conducted using a standard multiple plankton sampler (MPS, Hydro-Bios Kiel), consisting of five opening/closing nets, each with $0.25 \mathrm{~m}^{2}$ mouth opening and $200 \mu \mathrm{m}$ mesh size. Two vertical hauls at a speed of $40 \mathrm{~m} \mathrm{~min}^{-1}$ were carried out at the Rijpfjorden stations at midday and midnight sampling, but there was no indication of any diel vertical migration occurring (data not shown). The MPS net was lowered up to approx. $10 \mathrm{~m}$ above the bottom and then hauled back to the surface to provide an integrated sample from five following depth layers: 0-20, 20-50, 50-100, 100-200 and 200-260 m (Table 1).

The MIK assemblage was sampled using an open Methot Isaacs Kidd trawl modified as a ring net with a mouth opening of $3.15 \mathrm{~m}^{2}$ (ICES 2013). The net was $12 \mathrm{~m}$ long, with a mesh size of $1500 \mu \mathrm{m}$, which reduced to $500 \mu \mathrm{m}$ mesh net in the last meter and a $10-\mathrm{L}$ cod end. The net was trawled for $10 \mathrm{~min}$ at a speed of $\sim 1.5$ knots $\left(0.75 \mathrm{~m} \mathrm{~s}^{-1}\right)$ at three depth horizons $(20,75$ and $225 \mathrm{~m})$ in Rijpfjorden with separate horizontal tows at each depth. A total of seven MIK casts were achieved at both midday and midnight (Table 2). Tow depth was controlled using the live feed from a Simrad PI depth sensor. After net recovery, the cod end was transferred immediately to a bucket and diluted up to the 9-L mark in the laboratory on board. Subsamples of $0.6 \mathrm{~L}$ were then taken after gentle mixing.

Neither net was fitted with a flowmeter mounted on both nets, so volumes of water filtered were estimated based on net opening, depth layer, towing speed and time assuming that MIK net's trajectory was horizontal. The volume of water sampled by MPS ranged from $5 \mathrm{~m}^{3}$ to $25 \mathrm{~m}^{3}$, while it was much higher for horizontally towed MIK net amounting from $1099 \mathrm{~m}^{3}$ up to $8723 \mathrm{~m}^{3}$. The exception was one day MIK haul from $75 \mathrm{~m}$ (where lots of ice in the surface water column appeared), in which the volume of seawater filtered amounted to $345 \mathrm{~m}^{3}$.

All zooplankton samples were preserved in $4 \%$ hexamethylenetetraminbuffered formaldehyde directly after collection. Zooplankton taxa were identified and counted under a stereomicroscope equipped with an ocular micrometer, according to the standard procedures described by Harris et al. (2000). Smallsized zooplankton below $5 \mathrm{~mm}$ (Copepoda except CIV and older copepodites stages of Calanus hyperboreus, juvenile stages of Pteropoda, Euphausiacea, Ostracoda, Amphipoda and Chaetognatha) were identified and counted in subsamples obtained from a fixed sample volume by automatic pipette (approximately 500 individuals). All large zooplankton taxa (older than CIV stages of C. hyperboreus, advanced developmental stages of Pteropoda, Euphausiacea, Amphipoda, Decapoda, Appendicularia, Chaetognatha and larval stages of Pisces) were sorted, identified and measured from the whole sample. At least ten first individuals from each large zooplankton taxon were measured in each sample. In case of longitudinal shape zooplankton (Euphausiacea, Amphipoda, Decapoda, Appendicularia), as a total length, distance from the top of a head/ tip of a rostrum to the end of the body was used (e.g. Søreide et al. 2003). In case of round shape zooplankton species (e.g. pteropod Limacina helicina), the 
diameter was used as an equivalent for total length (Gannefors et al. 2005). All representatives of Calanus spp. were identified to species level based on morphology and prosome lengths of individual copepodite stages ( $c f$. Tande 1991; Kwaśniewski et al. 2003).

Previously, Webster et al. (2015) published the MIK data from the same cruise, along with multifrequency acoustics, to describe the vertical distribution of macrozooplankton biomass over a diel cycle, while MPS data have been presented for biomass comparison of protist and mesozooplankton in two contrasting locations: a shallow Rijpfjorden and a deep ice-covered region of Sofiadjupet (Błachowiak-Samołyk et al. 2015).

Data analyses. - The abundance data for the different developmental stages of the dominant copepod species and other zooplankton were converted to the number of individuals in $1 \mathrm{~m}^{3}$ and displayed graphically. There were no statistically significant differences between day and night abundances and sizes (data not shown) within either the MPS or the MIK samples, so the values from each sampling stratum were averaged separately for the MPS $(0-20 \mathrm{~m}$, 20-50 m, 50-100 m, 100-200 m and 200-260 m) and MIK (20 m, $75 \mathrm{~m}$ and $225 \mathrm{~m}$ ). It was confirmed by our data that two MPS sampling stations located $\sim 30 \mathrm{~km}$ apart were similar concerning bottom depth, water masses distribution and assemblages of zooplankton, so we decided to present obtained results as mean zooplankton abundances from both MPS 1 and MPS 2 stations following the pattern published in Błachowiak-Samołyk et al. (2015).

We used a similarity percentages analysis (SIMPER) to assess which species discriminated between the data from the two samplers. This analysis was run using PRIMER version 6.0 (Plymouth Marine Laboratory, Plymouth, UK) (Clarke and Warwick 1994).

All appropriate Calanus finmarchicus and $C$. glacialis copepodite stages were combined into Calanus spp. category when their patterns in vertical distribution were analysed (Fig. 5).

The size data for the individual taxa, which had a constant variance and were normally distributed, were examined by a standard t-test with the software STATISTICA v.9.1 (StatSoft, Inc. 2010). Additionally, a Spearman rank test was employed to test for any correlation between zooplankton size and frequency in MPS and MIK samples.

\section{Results}

MPS and MIK community structures. - A total of 49 taxa were sampled by the two nets. Of these 22 were exclusive to the MPS samples and 11 to the MIK samples, so only 16 taxa were sampled by both gears (Table 3 ). The copepods 
Oithona similis and Pseudocalanus spp. contributed 33\% and 30\% respectively to the total zooplankton abundances in the MPS samples, and Calanus finmarchicus and $C$. glacialis contributed $16 \%$ and $6 \%$, respectively. In contrast, $C$. finmarchicus and $C$. glacialis were numerically dominant in the MIK samples, contributing $51 \%$ and $28 \%$, respectively, to the total zooplankton abundance. Metridia longa (11\%) and $C$. hyperboreus (6\%) were third and fourth in overall zooplankton abundance in MIK samples. The 16 taxa common to both sets of samples included the older stages (> CIII) of Calanus spp., larger copepod species (Paraeuchaeta spp. and Bradyidius similis), chaetognaths (predominantly Parasagitta elegans), euphausiids (Thysanoessa longicaudata), gelatinous zooplankton (the ctenophores Beröe cucumis and Mertensia ovum) and other zooplankters (highlighted in grey in Table 3). Species exclusively sampled by the MPS included the smaller sizes of copepod (e.g. different development stages of O. similis, Triconia borealis, Microcalanus spp., Pseudocalanus spp.), young stages of Calanus spp. (CIII), young stages of pteropods (Clione limacina and Limacina helicina), appendicularians (Oikopleura spp. and Fritillaria borealis) and smaller gelatinous zooplankton (Aglantha digitale $\leq 5 \mathrm{~mm}$, Ctenophora larvae and Hydrozoa). In the MIK net samples, large zooplankters, such as larval stages of polychaetes, older stages of pteropods (C. limacina), euphausiids, amphipods and larger gelatinous animals (hydromedusa A. digitale $>5 \mathrm{~mm}$ ) (Table 3 ) were abundant.

The SIMPER analysis revealed that average dissimilarities in zooplankton community composition between MPS and MIK net samples was around 67\%. Oithona similis was the species contributing most (10\%) to difference between the data for the MPS and MIK samples. Other small and abundant taxa in the MPS samples included Pseudocalanus spp. (with 6-7\% contribution to dissimilarity of copepodite stages from CI to CV), adults T. borealis (with $6 \%$ contribution), Microcalanus spp. (5\%), C. finmarchicus CIV (3\%), small ( $<5 \mathrm{~mm})$ specimens of Oikopleura spp. (3\%) and adult males of M. longa (3\%) contributed to the dissimilarity between the two sets of samples. 
Table 3

Frequency of all identified zooplankton taxa/species/stages found in MPS and MIK together with average abundance, separately in MPS and MIK and their contribution to dissimilarity (SIMPER). The common MPS and MIK group present in both net types are highlighted by grey.

\begin{tabular}{|c|c|c|c|c|c|}
\hline \multirow[t]{2}{*}{ Taxon } & \multicolumn{2}{|c|}{$\begin{array}{l}\text { Frequency } \\
\text { of all taxa } \\
\text { identified in }\end{array}$} & \multicolumn{2}{|c|}{$\begin{array}{l}\text { Average } \\
\text { abundance } \\
\left(\text { ind. } \mathrm{m}^{-3}\right) \text { in }\end{array}$} & \multirow{2}{*}{$\begin{array}{l}\text { Contribu- } \\
\text { tion to } \\
\text { dissimilarity }\end{array}$} \\
\hline & MPS & MIK & MPS & MIK & \\
\hline Acartia longiremis (Lilljeborg, 1853) CI-CVI & 100 & 0 & 0.06 & 0 & 0.08 \\
\hline Aetideidae CI-CIII & 100 & 0 & 1.18 & 0 & 1.96 \\
\hline Aglantha digitale (O.F. Müller, 1776) $=<5 \mathrm{~mm}$ & 100 & 0 & 0.01 & 0 & 0.02 \\
\hline Bivalvia veliger & 100 & 0 & 0.09 & 0 & 0.15 \\
\hline Calanus finmarchicus (Gunnerus, 1770) CIII & 100 & 0 & 0.75 & 0 & 1.28 \\
\hline Calanus glacialis Jaschnov, 1955 CIII & 100 & 0 & 0.98 & 0 & 1.57 \\
\hline Calanus hyperboreus Krøyer, 1838 CIII & 100 & 0 & 0.11 & 0 & 0.19 \\
\hline Clione limacina (Phipps, 1774) $<5 \mathrm{~mm}$ & 100 & 0 & 0.04 & 0 & 0.06 \\
\hline Copepoda nauplii & 100 & 0 & 0.3 & 0 & 0.59 \\
\hline Ctenophora larvae & 100 & 0 & 0.42 & 0 & 0.65 \\
\hline Cyclocaris guilelmi Chevreux, 1899 & 100 & 0 & 0.01 & 0 & 0.01 \\
\hline Echinodermata larvae & 100 & 0 & 0.1 & 0 & 0.17 \\
\hline Fritillaria borealis Lohmann, 1896 & 100 & 0 & 0.12 & 0 & 0.19 \\
\hline Gastropoda veliger & 100 & 0 & 0.24 & 0 & 0.37 \\
\hline Harpacticoida indet. & 100 & 0 & 0.15 & 0 & 0.27 \\
\hline Hydrozoa medusae indet. & 100 & 0 & 0.09 & 0 & 0.14 \\
\hline Isopoda Bopyridae & 100 & 0 & 0.47 & 0 & 0.76 \\
\hline Limacina helicina (Phipps, 1774) $<5 \mathrm{~mm}$ & 100 & 0 & 1 & 0 & 1.7 \\
\hline Metridia longa (Lubbock, 1854) CI-CIV & 100 & 0 & 0.32 & 0 & 0.52 \\
\hline Microcalanus spp. & 100 & 0 & 2.76 & 0 & 4.75 \\
\hline Oikopleura spp. $<5 \mathrm{~mm}$ & 100 & 0 & 1.63 & 0 & 2.75 \\
\hline Oithona atlantica Farran, 1908 & 100 & 0 & 1.17 & 0 & 1.92 \\
\hline Oithona similis Claus, 1866 & 100 & 0 & 5.25 & 0 & 9.14 \\
\hline Ostracoda & 100 & 0 & 0.02 & 0 & 0.03 \\
\hline Pseudocalanus minutus (Krøyer, 1845) AF & 100 & 0 & 0.56 & 0 & 0.96 \\
\hline Pseudocalanus spp. CI-CV & 100 & 0 & 2.44 & 0 & 4.19 \\
\hline Pseudocalanus spp. AM & 100 & 0 & 0.13 & 0 & 0.23 \\
\hline Pseudomma truncatum S.I. Smith, 1879 & 100 & 0 & 0.02 & 0 & 0.03 \\
\hline
\end{tabular}


Table 3 - continued

\begin{tabular}{|c|c|c|c|c|c|}
\hline \multirow[t]{2}{*}{ Taxon } & \multicolumn{2}{|c|}{$\begin{array}{c}\text { Frequency } \\
\text { of all taxa } \\
\text { identified in }\end{array}$} & \multicolumn{2}{|c|}{$\begin{array}{l}\text { Average } \\
\text { abundance } \\
\left(\text { ind. } \mathrm{m}^{-3}\right) \text { in }\end{array}$} & \multirow{2}{*}{$\begin{array}{l}\text { Contribu- } \\
\text { tion to } \\
\text { dissimilarity }\end{array}$} \\
\hline & MPS & MIK & MPS & MIK & \\
\hline Triconia borealis (G.O. Sars, 1918) & 100 & 0 & 1.68 & 0 & 2.88 \\
\hline Travisiopsis spp. & 100 & 0 & 0.16 & 0 & 0.28 \\
\hline Beroe cucumis Fabricius, 1780 & 98 & 2 & 1.19 & 0.11 & 1.87 \\
\hline Mertensia ovum (Fabricius, 1780) & 91 & 9 & 0.05 & 0.01 & 0.08 \\
\hline Calanus hyperboreus Krøyer, 1838 CIV & 73 & 27 & 1.16 & 0.71 & 1.69 \\
\hline Bradyidius similis (G.O. Sars, 1902) CIV-CVI & 71 & 29 & 0.13 & 0.07 & 0.3 \\
\hline Calanus glacialis Jaschnov, 1955 CIV & 71 & 29 & 2.81 & 2.13 & 2.28 \\
\hline Paraeuchaeta spp. CV & 69 & 31 & 0.02 & 0.01 & 0.05 \\
\hline Calanus finmarchicus (Gunnerus, 1770) CIV & 69 & 31 & 3.61 & 2.49 & 3.26 \\
\hline Calanus finmarchicus (Gunnerus, 1770) CV & 54 & 46 & 4.04 & 3.66 & 2.18 \\
\hline Calanus glacialis Jaschnov, 1955 AM & 47 & 53 & 1.17 & 1.54 & 1.33 \\
\hline Parasagitta elegans (Verrill, 1873) $\Rightarrow>10 \mathrm{~mm}$ & 42 & 58 & 0.16 & 0.3 & 0.4 \\
\hline Paraeuchaeta norvegica (Boeck, 1872) AF & 41 & 59 & 0.01 & 0.02 & 0.04 \\
\hline Calanus glacialis Jaschnov, 1955 CV & 41 & 59 & 2.27 & 2.56 & 2.11 \\
\hline Calanus hyperboreus Krøyer, 1838 AM & 35 & 65 & 0.1 & 0.25 & 0.42 \\
\hline Apherusa glacialis (Hansen, 1888) & 32 & 68 & 0.01 & 0.04 & 0.07 \\
\hline Metridia longa (Lubbock, 1854) AF & 30 & 70 & 0.89 & 1.54 & 1.93 \\
\hline Metridia longa (Lubbock, 1854) CV & 28 & 72 & 0.92 & 1.2 & 2.08 \\
\hline Eukrohnia hamata (Möbius, 1875) => $10 \mathrm{~mm}$ & 24 & 76 & 0.2 & 0.65 & 0.86 \\
\hline Thysanoessa longicaudata (Krøyer, 1846) & 24 & 76 & 0.05 & 0.21 & 0.29 \\
\hline Calanus finmarchicus (Gunnerus, 1770) AF & 22 & 78 & 0.96 & 1.92 & 2.24 \\
\hline Calanus glacialis Jaschnov, 1955 AF & 18 & 82 & 1.47 & 2.67 & 2.4 \\
\hline Parasagitta elegans (Verrill, 1873) $\Rightarrow 20 \mathrm{~mm}$ & 17 & 83 & 0.57 & 1.55 & 1.83 \\
\hline Metridia longa (Lubbock, 1854) AM & 14 & 86 & 0.87 & 2.15 & 2.59 \\
\hline Eukrohnia hamata (Möbius, 1875) => 20 mm & 11 & 89 & 0.03 & 0.26 & 0.38 \\
\hline Calanus hyperboreus Krøyer, 1838 CV & 7 & 93 & 0.23 & 1.71 & 2.45 \\
\hline Calanus finmarchicus (Gunnerus, 1770) AM & 5 & 95 & 0.2 & 1.65 & 2.34 \\
\hline Calanus hyperboreus Krøyer, 1838 AF & 4 & 96 & 0.13 & 1.52 & 2.21 \\
\hline Aglantha digitale (O.F. Müller, 1776) $>5 \mathrm{~mm}$ & 0 & 100 & 0 & 0.4 & 0.58 \\
\hline Appendicularia larvae & 0 & 100 & 0 & 0.008 & 0 \\
\hline Caligus spp. & 0 & 100 & 0 & 0.004 & 0 \\
\hline
\end{tabular}




\begin{tabular}{|c|c|c|c|c|c|}
\hline \multirow[t]{2}{*}{ Taxon } & \multicolumn{2}{|c|}{$\begin{array}{l}\text { Frequency } \\
\text { of all taxa } \\
\text { identified in }\end{array}$} & \multicolumn{2}{|c|}{$\begin{array}{c}\text { Average } \\
\text { abundance } \\
\left(\text { ind. } \mathrm{m}^{-3} \text { ) in }\right.\end{array}$} & \multirow{2}{*}{$\begin{array}{l}\text { Contribu- } \\
\text { tion to } \\
\text { dissimilarity }\end{array}$} \\
\hline & MPS & MIK & MPS & MIK & \\
\hline Clione limacina $($ Phipps, 1774) $=>5 \mathrm{~mm}$ & 0 & 100 & 0.45 & 0.06 & 0.72 \\
\hline Erythrops erythrophthalmus (Goës, 1864) & 0 & 100 & 0 & 0.003 & 0 \\
\hline Gaetanus tenuispinus (G.O. Sars, 1900) CIV-VI & 0 & 100 & 0 & 0.006 & 0 \\
\hline Hyperia galba (Montagu, 1815) & 0 & 100 & 0 & 0.004 & 0 \\
\hline Hyperoche medusarum (Krøyer, 1838) & 0 & 100 & 0 & 0.02 & 0.03 \\
\hline Limacina helicina (Phipps, 1774) $\Rightarrow>5 \mathrm{~mm}$ & 0 & 100 & 0 & 0.16 & 0.3 \\
\hline Paraeuchaeta spp. AM & 0 & 100 & 0 & 0.01 & 0.03 \\
\hline Polychaete larvae & 0 & 100 & 0 & 0.07 & 0.14 \\
\hline Thysanoessa raschii (M. Sars, 1864) & 0 & 100 & 0 & 0.04 & 0.05 \\
\hline $\begin{array}{l}\text { Themisto libellula (Lichtenstein in Mandt, 1822) } \\
=>5 \mathrm{~mm}\end{array}$ & 0 & 100 & 0 & 0.05 & 0.06 \\
\hline Themisto abyssorum $($ Boeck, 1871) $=>5 \mathrm{~mm}$ & 0 & 100 & 0 & 0.07 & 0.1 \\
\hline Thysanoessa inermis (Krøyer, 1846) & 0 & 100 & 0 & 0.16 & 0.24 \\
\hline
\end{tabular}

\section{Vertical distribution patterns in abundance of larger zooplankton.}

- There was a consistent pattern in the vertical distribution of gelatinous zooplankters in the two nets. Mertensia ovum peaked numerically at 50-100 m in the MPS samples and at $75 \mathrm{~m}$ in MIK samples (Fig. 2a). Beröe cucumis was caught in higher abundances in MPS samples (maximum 10.3 ind. $\mathrm{m}^{-3}$ ) than in MIK samples $\left(0.22\right.$ ind. $\left.\mathrm{m}^{-3}\right)$ but the peak abundances were found in the upper water layers in both nets (Fig. 2b).

Both chaetognaths, Parasagitta elegans and Eukrohnia hamata, were sampled in the greatest numbers in the surface layer $(0-20 \mathrm{~m})$ in MPS. However, their abundance was four times greater in the MIK at $75 \mathrm{~m}$ depth (Figs. 3a-b). The only euphausiid species sampled by both nets was Thysanoessa longicaudata, which was most abundant $\left(0.16\right.$ ind. $\left.\mathrm{m}^{-3}\right)$ in the deepest layer $(200-260 \mathrm{~m})$ sampled by the MPS but was almost two times higher $\left(0.3\right.$ ind. $\left.\mathrm{m}^{-3}\right)$ at a shallower layer (75 m) in MIK samples (Fig. 4a). Two other euphausiid species, T. inermis and T. raschii, both occurred at their highest abundances in the upper water layers sampled by the MIK (Fig. 4b-c).

Copepodites CIV (Fig. 5a) and CV (Fig. 5b) of Calanus spp. (combined appropriate stages of Calanus finmarchicus and C. glacialis) were dominant in the upper $20 \mathrm{~m}$ layer in MPS samples (176 and 178 ind. $\mathrm{m}^{-3}$, respectively), while at $75 \mathrm{~m}$ in MIK samples (60 and 155 ind. $\mathrm{m}^{-3}$, respectively). There was a similar vertical distribution pattern in adults Calanus spp., which maximum 


\section{MPS MIK}

(a)

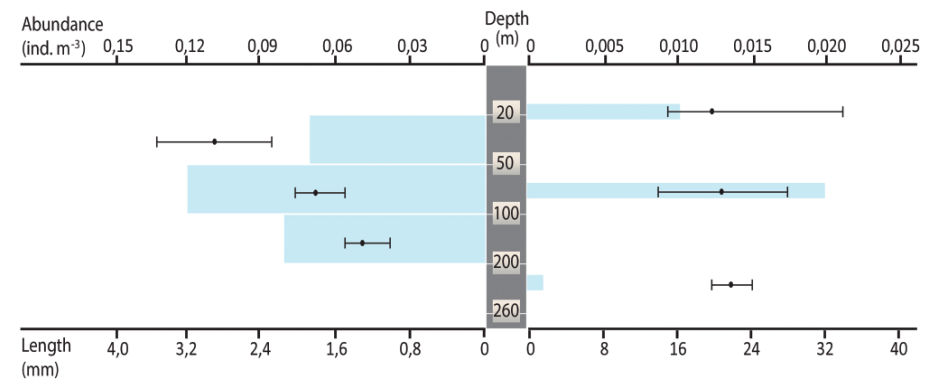

(b)

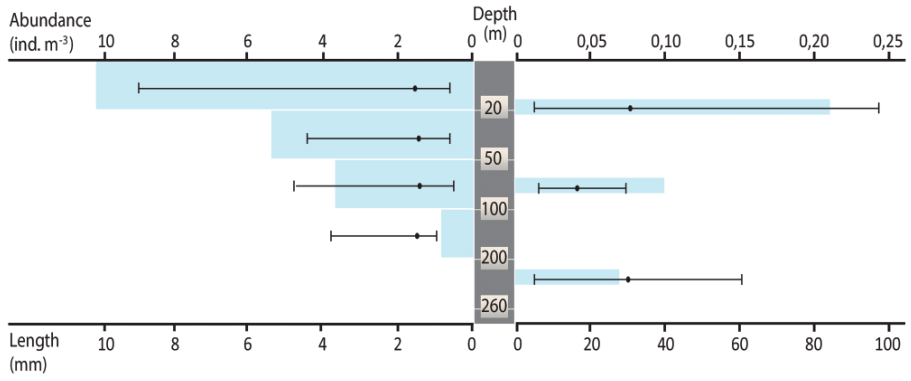

Abundance (ind. $\mathrm{m}^{-3}$ ) $\longmapsto$ MIN-AVG-MAX length (mm)

Fig. 2. Vertical distribution patterns of larger zooplankton taxa abundances (ind. $\mathrm{m}^{-3}$ ) and lengths (mm) in MPS (left panel) and MIK (right panel): a) Mertensia ovum; b) Beröe cucumis.

Note scale differences.

concentrations were in the surface layer in both samplers with a peak of females and males in the MIK samples (50 and 13 ind. $\mathrm{m}^{-3}$, respectively) (Figs $5 \mathrm{c}-\mathrm{d}$ ).

Concerning Calanus hyperboreus vertical distribution, CIV and CV copepodites were the most abundant stages $\left(6.7\right.$ ind $\left.\mathrm{m}^{-3}\right)$ at $200-260 \mathrm{~m}$ in the MPS samples and at $75 \mathrm{~m}$ (15.1 ind. $\left.\mathrm{m}^{-3}\right)$ in the MIK samples, respectively (data not shown).

After including all development stages (also CIII present exclusively in MPS samples) of Calanus spp. (combined Calanus finmarchicus and C. glacialis) from the integrated water column a consistent pattern of frequency of particular copepodites stages was obtained (Fig. 6a). Shares of the youngest CIII and CIV stages were the highest in MPS samples (3\% and 43\%, respectively) while $\mathrm{CV}$ and adult females/males prevailed in MIK samples (53\% and 20\%/6\%, respectively) (Fig. 6a). Similar consistency appeared when the frequency of 
MPS MIK

(a)

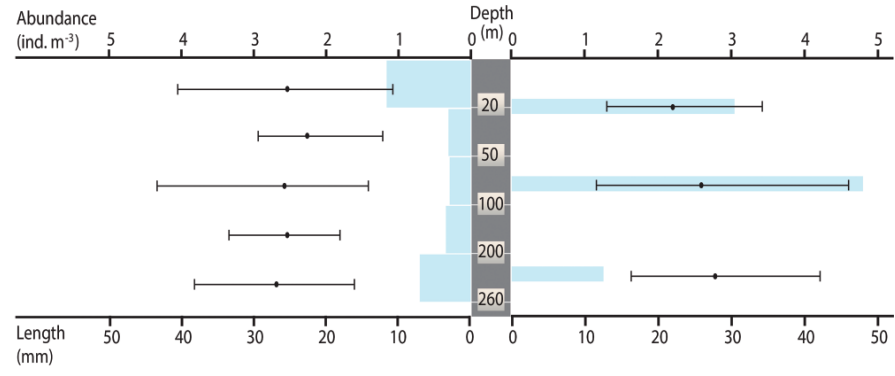

(b)

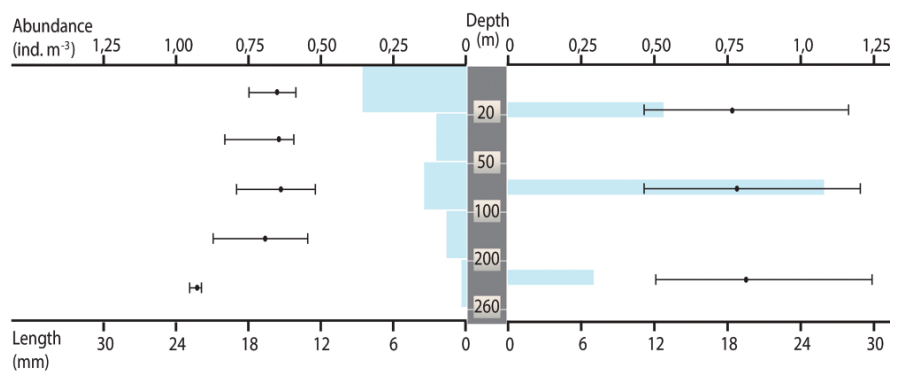

Abundance (ind. $\mathrm{m}^{-3}$ )

Fig. 3. Vertical distribution patterns of larger zooplankton taxa abundances (ind. $\mathrm{m}^{-3}$ ) and lengths (mm) in MPS (left panel) and MIK (right panel): a) Parasagitta elegans and b) Eukrohnia hamata. Note scale differences.

C. hyperboreus stages from the integrated water column was compared between the two nets. Dominant copepodite was CIV in MPS (79\%), but CV in MIK $(55 \%)$ (Fig. 6b). Moreover, the share of females in MIK samples was almost 10-folds higher than in MPS samples (Fig. 6b).

Vertical distribution patterns in size of larger zooplankton. - A Spearman rank correlation $\left(\mathrm{r}_{\mathrm{s}}=0.72, \mathrm{p}<0.001\right)$ between zooplankton size and frequency of occurrence showed that significantly more large individuals were collected by the MIK than the MPS net. The detailed vertical size patterns are described on figures 3-4. The ctenophores Mertensia ovum (Fig. 2a) and Beröe cucumis (Fig. 2b) showed large variability in their body lengths between the different depths in both nets. Specimens of Parasagitta elegans (Fig. 3a) and Eukrohnia hamata (Fig. 3b) were generally larger in deeper waters. Also Thysanoessa 


\section{MPS MIK}

(a)

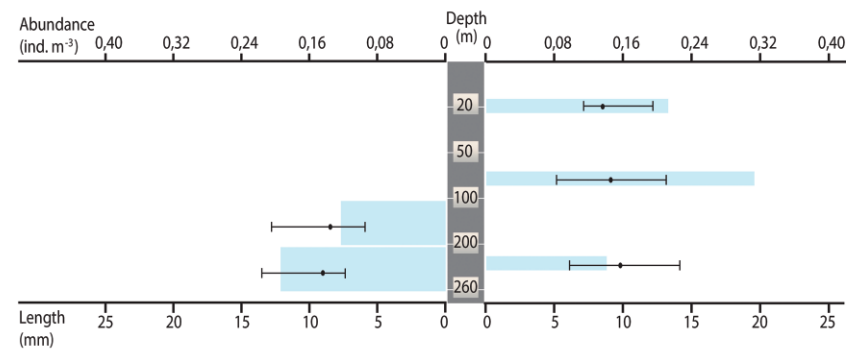

(b)

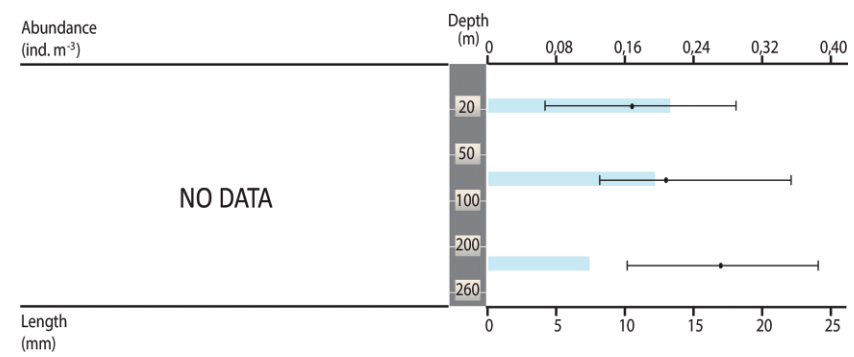

(c)

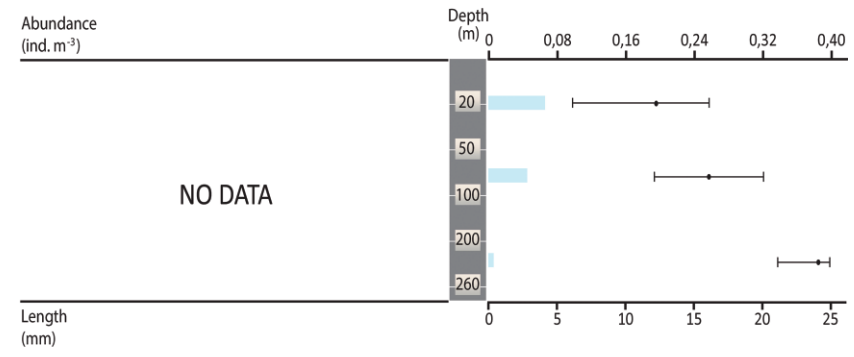

Abundance (ind. $\mathrm{m}^{-3}$ ) $\longmapsto$ MIN-AVG-MAX length (mm)

Fig. 4. Vertical distribution patterns of larger zooplankton taxa abundances (ind. $\mathrm{m}^{-3}$ ) and lengths (mm) in MPS (left panel) and MIK (right panel): a) Thysanoessa longicaudata; b) Thysanoessa inermis and c) Thysanoessa raschii. 
MPS MIK

(a)

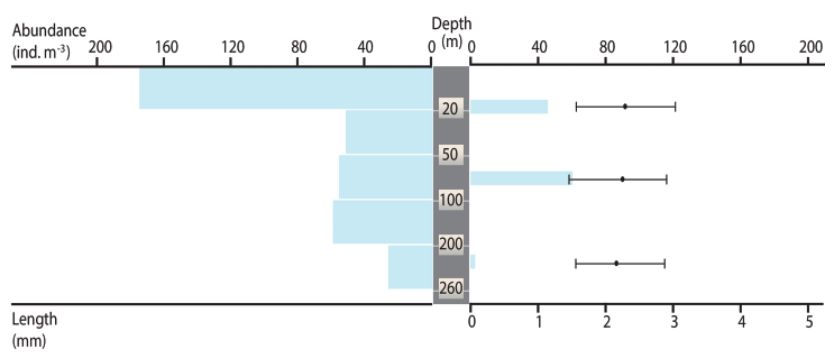

(b)

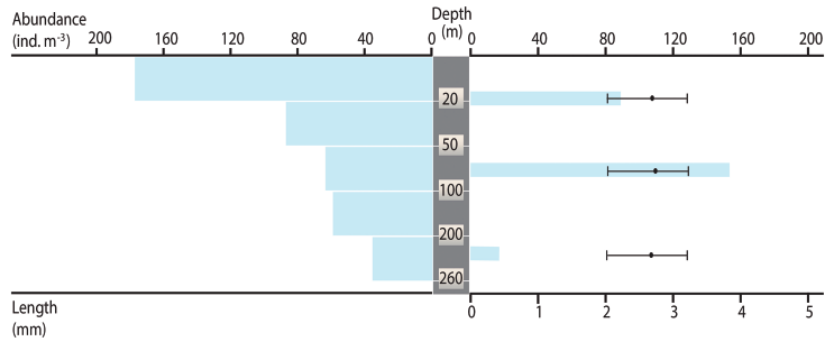

(c)

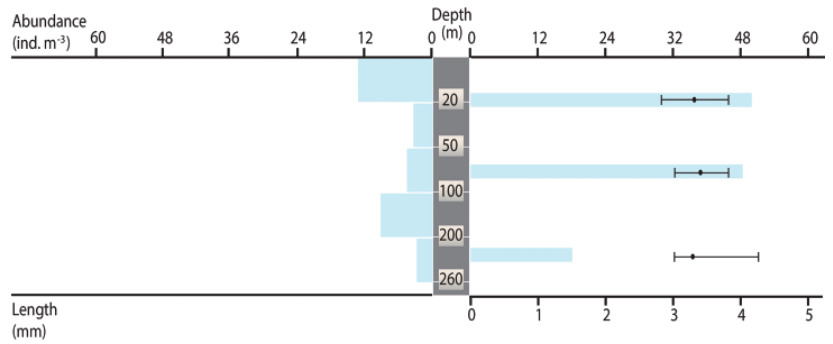

(d)

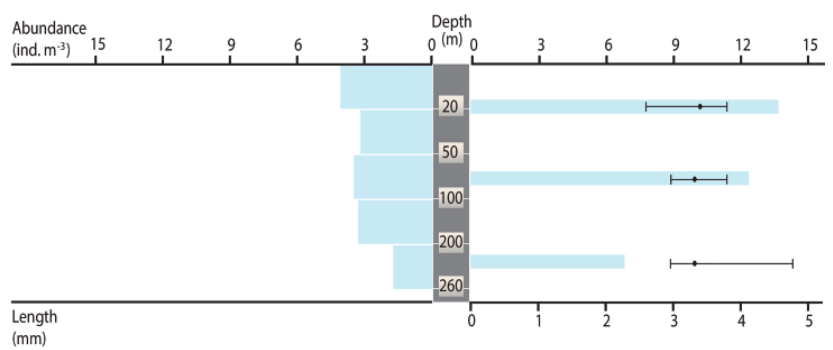

Abundance (ind. $\mathrm{m}^{-3}$ ) $\longmapsto$ MIN-AVG-MAX length (mm)

Fig. 5. Vertical distribution patterns of older copepodite stages of Calanus spp. (pooled both C. finmarchicus and C. glacialis) abundances (ind. $\mathrm{m}^{-3}$ ) in MPS (left panel) and MIK (right panel): a) copepodite stage IV (CIV); b) copepodite stage V (CV); c) copepodite stage VI - adult females (AF) and d) copepodite stage VI - adult males (AM). Note scale differences. 
(a)

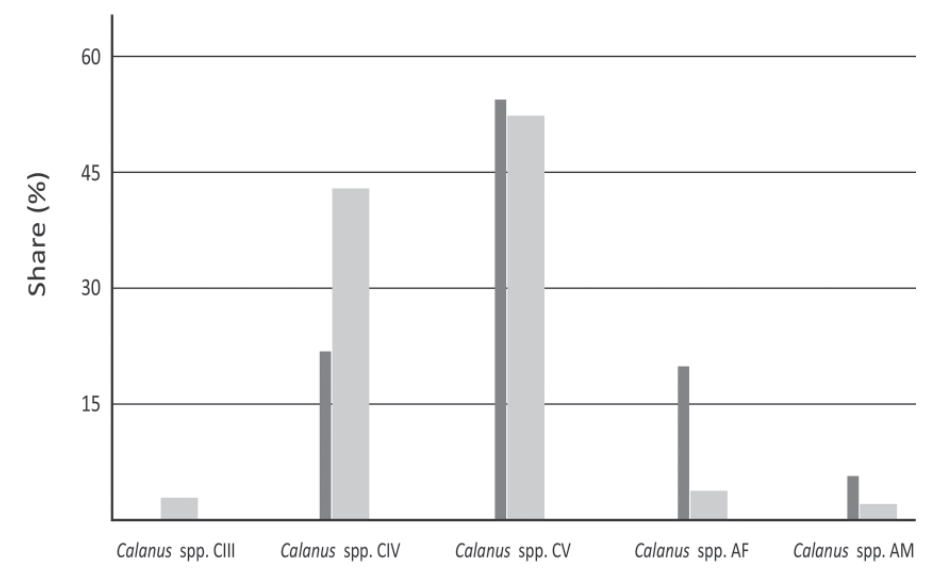

(b)

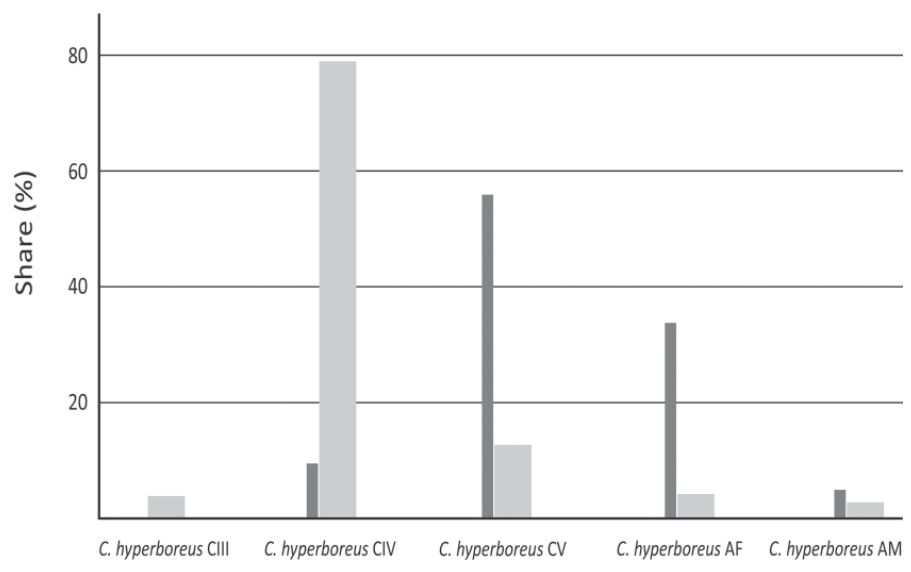

Copepodite stage

Fig. 6. Shares (\%) of particular copepodite stages of: a) Calanus spp. (including C. finmarchicus and C. glacialis); b) C. hyperboreus integrated from all sampling layers from both gears (MPS and MIK).

longicaudata were larger in the deep layers (Fig. 4a), like the T. inermis and T. raschii, which were caught exclusively by MIK net (Fig. 4b-c).

Although there were consistent patterns of vertical variability within lengths of all stages of three Calanus we included only the results from MIK in Fig. 5. The MPS measurements, which were provided according to classification to the species level based on prosome lengths ranges of individual copepodites stages of all Calanus spp. (Kwaśniewski et al. 2003), are displayed in Table 4. 
Table 4

The results of measurements of prosome lengths and widths $(\mu \mathrm{m})$

of three Calanus species found in our zooplankton samples.

\begin{tabular}{|c|c|c|c|}
\hline \multirow{2}{*}{ Calanus development stage } & \multicolumn{2}{|c|}{ Average prosome $(\mu \mathrm{m})$} & \multirow{2}{*}{ Number of ind. measured } \\
\hline & length & width & \\
\hline C. finmarchicus CIV & 1997 & 524 & 49 \\
\hline C. finmarchicus $\mathrm{CV}$ & 2509 & 685 & 71 \\
\hline C. finmarchicus CVI, AF & 3002 & 796 & 80 \\
\hline C. finmarchicus CVI, AM & 3100 & 801 & 38 \\
\hline C. glacialis CIV & 2551 & 668 & 45 \\
\hline C. glacialis $\mathrm{CV}$ & 3157 & 1029 & 57 \\
\hline C. glacialis $\mathrm{CVI}, \mathrm{AF}$ & 3573 & 1126 & 70 \\
\hline C. glacialis CVI, AM & 3602 & 1143 & 44 \\
\hline C. hyperboreus CIV & 3603 & 1056 & 81 \\
\hline C. hyperboreus CV & 4890 & 1486 & 90 \\
\hline C. hyperboreus CVI, AM & 6458 & 1487 & 78 \\
\hline C. hyperboreus CVI, AM & 6220 & 1400 & 19 \\
\hline
\end{tabular}

\section{Discussion}

This study revealed that a relatively diverse zooplankton community exists in Rijpfjorden during the midwinter, with a total of 49 zooplankton taxa being recorded in the samples collected using the two nets. Thus, the assemblage observed is richer concerning species diversity than if a single sampler had been used. For example only 42 taxa were collected in a seasonal study using just the MPS in the same region from March to October 2007 (Weydmann et al. 2013). Composition of the midwinter zooplankton community sampled by the MPS was dominated by Pseudocalanus spp. and Oithona similis, but Calanus finmarchicus and $C$. glacialis were also present in relatively large numbers; an observation similar to that reported by Weydmann et al. (2013) during autumn.

Only 16 of the total number of 49 zooplankton taxa sampled were common to both samplers; all of these were of intermediate size. So as expected, the small copepod species, gelatinous zooplankters and the young stages of pteropods and appendicularians were exclusively collected by the MPS; they would have been extruded through the large meshes of the MIK. Conversely, the large zooplankton, such as polychaetes, older stages of pteropods, appendicularians, 
euphausiids, amphipods, and large gelatinous zooplankton were only taken by the bigger, more rapidly towed MIK net. The SIMPER analysis confirmed, there were distinct differences in the zooplankton community composition and structure sampled by the MPS net and the MIK net; the small copepod $O$. similis, which was not retained by the large mesh size of the MIK, contributed most to this differentiation.

Vertical distribution patterns in abundance and size of large zooplankters. Large zooplankton such as euphausiids are fast swimmers (Vinogradov 1997) and may avoid small nets such as the MPS, which leads to considerable underestimation of the large size fraction when using standard mesozooplankton sampling gear (Sameoto et al. 2000). In this survey, by studying vertical distribution patterns using two contrasting gears, we have attempted to broaden the outlook for larger zooplankton community.

The two ctenophore species, Beröe cucumis and Mertensia ovum, were generally found at low abundance, which is in agreement with previous reports (e.g. Swanberg and Båmstedt 1991). Surprisingly high numbers of tiny Beröe cucumis were found only in the MPS samples (with a maximum abundance of 10 ind. $\mathrm{m}^{-3}$ ), which is in accordance with Falkenhaug (1996) who observed very high biovolumes of this species in winter in northern Norway fjord. Otherwise, generally low abundances of gelatinous zooplankton we observed in MIK samples is consistent with the results of the seasonal study of macrozooplankton in Billefjorden, Svalbard $\left(78^{\circ} 40^{\prime} \mathrm{N}\right)$ (Bandara et al. 2016), in which the vertical distributions of the larger $(>1000 \mu \mathrm{m})$ zooplankton were assessed using vertical hauls (WP-3 net; $1000 \mu \mathrm{m}$ mesh size) from three depth strata $(0-50,50-100$ and 100-180 m) between August 2008 and May 2009. In interpreting the results of this study, it was assumed that both ctenophore species had descended to occupy deeper depths between August and October and then ascended back up to shallower depths from November. In Rijpfjorden our study shows that the abundance of $M$. ovum peaked at the intermediate depths (50-100 m depth layer in MPS samples and $75 \mathrm{~m}$ in MIK samples). Whereas the results of both nets showed that $B$. cucumis was concentrated at the surface $20 \mathrm{~m}$. The autumn descent (and spring-summer ascend) is likely a response to the migrations of their prey (Bandara et al. 2016). Mertensia ovum feeds predominantly on Calanus spp., which during our Rijpfjorden study was also concentrated in the upper water column, whereas B. cucumis is a tertiary consumer that feeds specifically on M. ovum (Swanberg and Båmstedt 1991). So the vertical distributions of both species, which were revealed by both nets in our survey, may be a consequence of a typical prey-predator relationship as described in the Barents Sea by Swanberg and Båmstedt (1991). As expected, the observed size distributions of ctenophores in our survey varied with the samplers: Mertensia ovum had average lengths of $2.1 \mathrm{~mm}$ in MPS compared with $21.4 \mathrm{~mm}$ in the MIK samples. The size disparity 
was even greater in B. cucumis, which had an average body size of $1.4 \mathrm{~mm}$ in MPS samples compared with $27 \mathrm{~mm}$ in MIK samples, but the maximum length values increased consequently towards the surface in both species and nets (Fig. 2a-b). Bandara et al. (2016), in their ten-month study in Billefjorden, reported that the populations of ctenophores were dominated by small specimens (mean annual body lengths were $6.7 \mathrm{~mm}$ for $M$. ovum and $2.9 \mathrm{~mm}$ for B. cucumis) but increased to $11 \mathrm{~mm}$ for $M$. ovum and $6 \mathrm{~mm}$ for $B$. cucumis in January 2009. In case of $M$. ovum the average value obtained in the same month as in our study in Billefjorden, is in agreement with our mean measurements from MPS and MIK, while it is much lower for B. cucumis sampled by MPS. It seems that the tiny but abundant population of B. cucumis was possible to be caught only by the net with the fine mesh size (e.g. MPS in our study), contrary to coarser WP-3 net used by Bandara et al. (2016). On the other hand, the size distributions of the last mentioned species inhabiting the northern Norway fjord (Falkenhaug 1996) demonstrated its size peak in winter (between 20 and $30 \mathrm{~mm}$ length), which seems to be in accordance with our MIK measurements (average $27 \mathrm{~mm}$ ). The large disparity in average body size of ctenophores we sampled was undoubtedly the result of the different mesh sizes of the samplers, but the absence of larger individuals in MPS showed that MIK sampled larger individuals $(>11 \mathrm{~mm})$ much more efficiently in comparison with MPS. Our results on the abundance and length distribution of these organisms contribute on bridging gaps in the general knowledge of ctenophores distribution/sizes, but also emphasize the need to use at least two nets with different characteristics to properly examine these zooplankton assemblages.

Some authors have suggested that chaetognaths do not have a distinct seasonal distribution pattern (e.g. Hagen 1999). However, Parasagitta elegans peaked in abundance in summer and autumn in Billefjorden, Svalbard (Grigor et al. 2014). Chaetognaths are known to aggregate during winter in the hyperbenthic zone immediately above the seafloor (Choe and Deibel 2000), and Grigor et al. (2014) found all cohorts of P. elegans in deeper waters during winter. This suggests they undertake seasonal migration, possibly to track the distribution of overwintering copepods. Our study lends support to this hypothesis since we observed that the maximum abundances of both Parasagitta elegans and Eukrohnia hamata coincided with the surface concentrations of the herbivorous Calanus spp. in water column at $0-20 \mathrm{~m}$ in the MPS samples and at $75 \mathrm{~m}$ in the MIK samples. Two recent winter studies from the Arctic found low abundances of the chaetognaths both in Kongsfjorden $-0.3-1.1$ ind. $\mathrm{m}^{-3}$ (Grenvald et al. 2016) and in Billefjorden - 2.4-14.7 ind. $\mathrm{m}^{-3}$ (Grigor et al. 2014), but these abundances were still higher than the ones we estimated in Rijpfjorden (0.3-1.2 ind. $\mathrm{m}^{-3}$ and 1.2-5.9 ind. $\mathrm{m}^{-3}$ in MPS and MIK samples, respectively). Similar patterns in the vertical distribution of P. elegans were reported in Billefjorfden in 2009 (Bandara et al. 2016) in which higher abundances were present both in the 
deepest layers and near the surface - observations that are consistent with our MPS data. Eukrohnia hamata occurred in low abundances $\left(0.02-0.35\right.$ ind. $\mathrm{m}^{-3}$ and $0.3-1.2$ ind. $\mathrm{m}^{-3}$ in MPS and MIK samples, respectively) (Fig. 3b) and mainly in the upper layers (0-20 $\mathrm{m}$ in the MPS and at $75 \mathrm{~m}$ in the MIK); this is in accord with Richter (1995) who reported that this species inhabits the subsurface layer in the Greenland Sea for most of the year.

Our morphometric data for P. elegans (average lengths $22 \mathrm{~mm}$ in MPS and $23 \mathrm{~mm}$ in MIK net) are in good agreement with other polar night results (e.g. Grigor et al. 2014; Bandara et al. 2016), which indicated that around $80 \%$ of the population of the first year generation had a mean total length of $23.4 \mathrm{~mm}$.

In Rijpfjorden in 2012 the euphausiids were mainly located in the upper waters but were caught in much larger numbers by the MIK than by the MPS; they are fast swimmers and so are able to avoid the smaller net. The most abundant euphausiid in our zooplankton material was the oceanic species Thysanoessa longicaudata. The coastal species T. inermis was also present and was the species dominating the macrozooplankton community in Kongsfjorden (Buchholz et al. 2010) where its high abundance (1.9-2.5 ind. $\mathrm{m}^{-3}$ ) occurred in January 2014 (Grenvald et al. 2016). The third euphausiid species caught by MIK was a neritic species $T$. raschii, which occurred in relatively low abundances (maximum 0.06 ind $\mathrm{m}^{-3}$ ) similar to those reported in Kongsfjorden (Buchholz et al. 2010; Grenvald et al. 2016 and citations therein). The vertical distribution patterns of all three Thysanoessa spp. (our data) showed that the highest abundances occurred in the shallower water layers; this is consistent with the observation of Williams and Lindley (1982) who reported that between March and October in the North-eastern Atlantic a large population of T. longicaudata was concentrated in the upper $100 \mathrm{~m}$. The clear pattern for the larger-sized euphausiids (all three species) to be deeper distributed in Rijpfjorden in January 2012 is consistent with the observations of Iguchi and Ikeda (2004) who reported a clear trend for larger specimens of Thysanoessa longipes to occur at deeper depths in the central Japan Sea. It was also confirmed in Kongsfjorden waters, that during polar night $T$. inermis and $T$. raschii overwinter in the deep and particularly so close to the sea bottom that a normally sampling zooplankton net could not reach them (Hirche et al. 2016), whereas the small half-yearlings individuals remained at the surface (F. Buchholz personal comm.). In Kongsfjorden, Grenvald et al. (2016) recorded the average length of T. inermis to be $12.2-12.8 \mathrm{~mm}$ in January 2014, whereas a broader range of sizes (10.3-16.7 mm) observed in Rijpfjorden in January 2012 might be the result of sampling three different depth layers (our study: $20 \mathrm{~m} ; 75 \mathrm{~m} ; 225 \mathrm{~m}$ ) contrary to only one layer (Grenvald et al. 2016: $20 \mathrm{~m}$ ).

This discrepancy might also suggest that both the knowledge on vertical distribution patterns and size structure of large zooplankters in various regions of Svalbard in midwinter is still scarce and need to be substantially supplemented. 
The overwintering stages of Calanus spp. - Preliminary identification of the three Calanus species was conducted by using prosome length criteria (Kwasniewski et al. 2003) and such categorisation was used in general description of Rijpfjorden zooplankton community structure in the current study (Tables 3 and 4). In less than a decade, next-generation sequencing technologies have fundamentally changed our approach to the recognition of Calanus species. Gabrielsen et al. (2012) found out that the morphological identification of Calanus in Svalbard (also in Rijpfjorden) waters systematically overestimates the abundance of $C$. finmarchicus at the expense of $C$. glacialis, which inspired us to combine appropriate copepodite stages of two C. finmarchicus and C. glacialis into Calanus spp. when tracking their vertical distribution (Fig. 5). We share the opinion that such misidentification poses a serious problem in the use of these two species as indicators of Atlantic versus Arctic water masses and thus as climatic indicators.

Typically, populations of two smaller Calanus species, C. finmarchicus and C. glacialis, overwinter at greater depths than they inhabit during vegetation period either as adults or as late stage copepodites (e.g. Wold et al. 2011). It has been shown that large numbers of CIV and CV copepodids of both C. finmarchicus and C. glacialis were already present in surface waters in our study (Fig. 5a-b), which is similar to the midwinter observations of Berge et al. (2015) from the same region. Two recent seasonal studies by Lischka and Hagen (2016) and Bandara et al. (2016) have also described seasonal vertical patterns in abundance of Calanus age structure sampled by a modified Apstein closing net $\left(100 \mu \mathrm{m}\right.$ mesh size, $0.2 \mathrm{~m}^{2}$ mouth opening) and a larger WP3 net (mesh size of $1000 \mu \mathrm{m}, 1 \mathrm{~m}^{2}$ area of the opening) in Kongsfjorden and Billefjorden, respectively. Lischka and Hagen (2016) reported that in February 1999 the dominant stage was CV of C. finmarchicus (>50\%), while stage CIV and females of $C$. glacialis ( $30 \%$ each); these observations are similar to our results from MPS samples (data not shown: CV of C. finmarchicus - 57\%; CIV and females of $C$. glacialis $-54 \%$ and $9 \%$, respectively).

Calanus spp. males, which are usually rare in typical mesozooplankton samples, were present mainly in November 1998 and February 1999 in the two deeper layers $(>50 \mathrm{~m})$ with the peak below $100 \mathrm{~m}$ depth in Kongsfjorden (Lischka and Hagen 2016). In comparable month with our study Bandara et al. (2016) reported that males of the two smaller Calanus species were distributed mostly in the upper $50 \mathrm{~m}$ of Billefjorden, which is similar to our observations $(0-20 \mathrm{~m})$ from Rijpfjorden (Fig. 5d).

The copepodite stages CIII and CIV of C. hyperboreus occurred almost exclusively in the MPS samples, whereas CV and adult females dominated the population in the MIK assemblage (our study; Fig. 6b), Although we are aware that partly responsible for the disproportion in numbers of older Calanus copepodites between both nets could be also the big difference in volume of 
filtered seawater by the two nets (the average $13 \mathrm{~m}^{3}$ for MPS vs. $4161 \mathrm{~m}^{3}$ for MIK), the comparison of the large MIK net in relation to small MPS results demonstrates very well supplementary role of both vertical distribution patterns.

In January 1999 the dominant CIV stage of $C$. hyperboreus was concentrated at the deepest sampled layer $(>100 \mathrm{~m}$ ) in Kongsfjorden (Lischka and Hagen 2016), which is in accordance with our data from both samplers.

Sampling considerations. - The mathematical model for assessing the selectivity of high-speed plankton nets in North Sea zooplankton developed by Nichols and Thompson (1991) estimated that $\sim 95 \%$ of copepods with a carapace width $\geq 75 \%$ of the sampler's mesh size are efficiently retained by a net. Gallienne and Robins (2001) also stated that the carapace width of the smallest target organism efficiently retained by mesh of a given size would be $75 \%$ of that mesh size. So it seems that the rule also applies to the more slowly hauled nets, as used in our survey (as well as in the other surveys mentioned above). When interpreting our detailed Calanus morphometric data (lengths and widths) it should be born in mind that $1125 \mu \mathrm{m}$ is $75 \%$ of the MIK mesh size. Thus only the older, larger-sized specimens will be efficiently retained by the larger net, i.e. only adults of $C$. glacialis, and late copepodite stages CIV-CV and adults of $C$. hyperboreus (Table 4).

Hence, our MIK data provide noteworthy supplementary information about the distributions, age structures and sizes of adults of two larger Calanus species, which are seldom taken in adequate numbers in mesozooplankton samplers such as the MPS. However, theoretically none of stages of $C$. finmarchicus have prosome widths broad enough to be retained effectively by the MIK net with $1500 \mu \mathrm{m}$ that we used. Bandara et al. (2016) also found that in Kongsfjorden only the older copepodites (with width $>750 \mu \mathrm{m}$ ) were taken representatively by their $1000 \mu \mathrm{m}$ mesh size sampler.

Summary. - Obtaining accurate estimates of a broad size spectrum of zooplankton species is important because data on diversity and abundances is the fundamental in order to understand ecological processes (e.g. estimation of carbon fluxes). The recent paper on plankton patchiness (Trudnowska et al. 2016) based on a laser optical plankton counter (LOPC), a fluorometer and CTD measurements (along several sections in the surface $50 \mathrm{~m}$ of the West Spitsbergen region with additional data from zooplankton net sampling and hydrographical measurements at stations), observed that zooplankton patches, which differed in terms of size, number and distribution patterns, occupied only a minor portion of the studied ocean area (2-17\%). It was also found in this study that two smaller (small and medium) zooplankton fractions distributions were sensitive to increased primary production, optimal hydrography, discontinuities in the density field and/or the presence of meanders/eddies, while large copepods size fraction (L: 0.8-5.0 mm Equivalent Spherical Diameter) were independent of 
any oceanographic feature, which pointed towards biological cues (e.g. seasonal and ontogenetic migration, food availability and predatory risk) as main factors regulating aggregation processes of macrozooplankton. Thus, in our study we have shown that horizontal plankton tows sampling much larger volumes of seawater (MIK) provide important, supplementary information on bigger zooplankton community structure in terms of age structure, abundance and sizes to those obtained from vertical MPS hauls. Combining data from these two samplers gave substantially higher estimates of the species diversity (49 taxa) than those based on the individual samplers (MPS: 38 taxa, MIK: 28). This is especially important in the context of the limited knowledge and accessibility to the midwinter zooplankton community in the high Arctic regions.

Additionally, our data demonstrated how much the large MIK net was more effective in sampling older stages (CIV-CVI, $>1125 \mu \mathrm{m}$ ) of larger Calanus species than the smaller MPS (the same would apply to other mesozooplankton samplers such as the WP2 and WP3 with fine mesh). The youngest stage present (CIII) of Calanus spp. was sampled exclusively by the MPS, and the share of CIV copepodites in MPS was double that than in MIK samples. In contrast, catches of the CV-CVI copepodites of Calanus spp. were substantially higher in the MIK samples (3-fold and 5-fold higher for adult males and females, respectively). Analogous comparison for $C$. hyperboreus gave even more striking result; almost 5-fold and 10-fold higher share of CV copepodites and adults females in MIK than MPS samples, respectively. Moreover, in the MIK samples greater numbers of all three Thysanoessa species occurred predominantly in the upper layers, but there was a clear tendency for the larger-sized euphausiids to occur deeper.

Consistent patterns for the vertical distributions of the large zooplankters (e.g. ctenophores) collected by the two gears provided far better data on their abundances and sizes than obtained by the samplers usually used (e.g. MPS). Additionally our results from both nets demonstrated that there were high abundances of Calanus spp. and their predators (ctenophores and chaetognaths) in the upper water layers.

This study has provided an initial snap-shot of how combined zooplankton sampling with two samplers with different characteristics (MPS and MIK) can deliver useful additional insights into the composition and size structure of zooplankton communities not only in the polar seas but elsewhere. By examining with special caution large zooplankters, our midwinter study delivered valuable knowledge on patchy and rare distributed animals (e.g. euphausiids or ctenophores), which provide a means of linking the structure of the zooplankton assemblages with that of the micronekton. 
Acknowledgements. - We are indebted to the captain and crew of the R/V Helmer Hanssen for their assistance in field. The cruise was part of the PhD course BIO-8510 at University of Troms $\emptyset$. This project was also a part of the Ecosystem Survey of Rijpfjorden run by the Centre for Ice, Climate and Ecosystem (ICE) at the Norwegian Polar Institute. Clare Webster was supported by funding from the Natural Environment Research Council (UK). This study received support from the Polish National Scientific Centre (2013/09/B/NZ8/03365) and Polish Ministry of Science and Higher Education for co-funding project IMOS, decision no. 3550/Norway/2016/2 for years 2016-2017. The authors are indebted to Agnieszka Terlecka for drawing figures 2-6. Special thanks to dr Martin Angel for many valuable advises on the content of the manuscript together with comprehensive English proofreading.

\section{References}

AntACli J.C., Hernández D. and SABATINI M.E. 2010. Estimating copepods' abundance with paired nets: Implications of mesh size for population studies. Journal of Sea Research 63: $71-77$.

Bandara K., VArpe Ø., Søreide J.E., Wallenschus J., Berge J. and Eiane K. 2016. Seasonal vertical strategies in a high-Arctic coastal zooplankton community. Marine Ecology Progress Series 555: 49-64.

BÅtnes A.S., Miljeteig C., Berge J., Greenacre M. and Johnsen G. 2015. Quantifying the light sensitivity of Calanus spp. during the polar night - potential for orchestrated migrations conducted by ambient light from the sun, moon, or aurora borealis? Polar Biology 38: 51-65.

Berge J., DaAse M., Renaud P.E., Ambrose Jr. W.G., Darnis G., Last K.S., Leu E., Cohen J.H., Johnsen G., Moline M.A., Cottier F., Varpe Ø., Shunatova N., BaŁazy P., Morata N., Massabuau J.-C., Falk-Petersen S., Kosobokova K., Hoppe C.J.M., WęSŁaWski J.M., KuKliński P., Legeżyńska J., Nikishina D., Cusa M., KędRa M., WŁodarska-Kowalczuk M., Vogedes D., Camus L., Tran D., Michaud E., GabrielsEN T.M., Granovitch A., Gonchar A., Krapp C.R. and CALlesen T.A. 2015. Unexpected Levels of Biological Activity during the Polar Night Offer New Perspectives on a Warming Arctic. Current Biology 25: 2555-2561.

BŁachowiak-SamoŁyk K., Wiktor J., Hegseth E.N., Wold A., Falk-Petersen S. and KUBISZYN A. 2015. Winter Tales - a dark side of planktonic life. Polar Biology 38: 23-36.

BuChHOLZ F., BUCHHOLZ C. and WESEAWSKI J.M. 2010. Ten years after: krill as indicator of change in the macro-zooplankton communities of two Arctic fjords. Polar Biology 33: 101-113.

ClARKE K.R. and WARWICK R.M. 1994. Changes in Marine Communities: An Approach to Statistical Analysis and Interpretation. Natural Environment Research Council, Plymouth: 176 pp.

Choe N. and DeIBel D. 2000. Seasonal vertical distribution and population dynamics of the chaetognath Parasagitta elegans in the water column and hyperbenthic zone of Conception Bay, Newfoundland. Marine Biology 137: 847-856.

DAASE M., VARPE O. and FAlK-PETERSEN S. 2014. Non-consumptive mortality in copepods: occurrence of Calanus spp. carcasses in the Arctic Ocean during winter. Journal of Plankton Research 36: 129-144.

FALKENHAUG T. 1996. Distributional and seasonal patterns of ctenophores in Malangen, northern Norway. Marine Ecology Progress Series 140: 59-70.

FalK-Petersen S., Leu E., Berge J., NygÅRd H., Røstad A., Keskinen E., Thormar J., Quill- 
FELDT C., Wold A. and GulliKSEN B. 2008. Vertical migration in high Arctic waters during autumn 2004. Deep-Sea Research II 55: 2275-2284.

FOLT C.L. and BURNS C.W. 1999. Biological drivers of zooplankton patchiness. Trends in Ecology and Evolution 14: 300-305.

Gabrielsen T., Merkel B., Søreide J., Johansson-Karlsson E., Bailey A., Vogedes D., NYGÅRD H., VARPE $\emptyset$. and BERGE J. 2012. Potential misidentifications of two climate indicator species of the marine arctic ecosystem: Calanus glacialis and C. finmarchicus. Polar Biology 35: $1621-1628$.

GALLIENNE C.P. and RoBins D.B. 2001. Is Oithona the most important copepod in the world's oceans? Journal of Plankton Research 23: 1421-1432.

Gannefors Ch., Boer M., Kattner G., Graeve M., Eiane K., Gulliksen B., Hop H. and FalK-PETERSEN S. 2005. The Arctic sea butterfly Limacina helicina: lipids and life strategy. Marine Biology 147: 169-177.

Grenvald J.C., CAllesen T.A., DaAse M., Hobbs L., DARnis G., Renaud P.E., CotTIER F., ToRKEL G.N. and BERGE J. 2016. Plankton community composition and vertical migration during polar night in Kongsfjorden. Polar Biology 39: 1879-1895.

GRIGOR J.J., SøREIDE J.E. and VARPE Ø. 2014. Seasonal ecology and life history strategy of the high-latitude predatory zooplankter Parasagitta elegans. Marine Ecology Progress Series 499: $77-88$.

HAGEN W. 1999. Reproductive strategies and energetic adaptations of polar zooplankton. Invertebrate Reproduction and Development 36: 25-34.

HARRIS R., Wiebe P., LenZ J., SkJOldal H.R. and HunTley M. (eds) 2000. ICES zooplankton methodology manual. Academic Press, London: 684 pp.

HIRCHE H.-J., LAUDIEN J., BUCHHOLZ F. 2016. Near-bottom zooplankton aggregations in Kongsfjorden: implications for pelago-benthic coupling. Polar Biology 39: 1897-1912.

HopCroft R.R., Clarke C., Nelson R.J. and Raskoff K.A. 2005. Zooplankton communities of the Arctic's Canada Basin: the contribution by smaller taxa. Polar Biology 28: 198-206.

ICES 2013. Manual for the Midwater Ring Net sampling during IBTS Q1. Series of International Council for the Exploration of the Sea Survey Protocols SISP 2-MIK 2, Copenhagen: 18 pp.

IGUCHI N. and IKEDA T. 2004. Vertical distribution, population structure and life history of Thysanoessa longipes (Crustacea: Euphausiacea) around Yamato Rise, central Japan Sea. Journal of Plankton Research 26: 1015-1023.

JOHNSON D.L. and FOGARTY M.J. 2013. Intercalibration of MOCNESS and Bongo nets: Assessing relative efficiency for ichthyoplankton. Progress in Oceanography 108: 43-71.

Kwasniewski S., Hop H., FalK-Petersen S. and Pedersen G. 2003. Distribution of Calanus species in Kongsfjorden, a glacial fjord in Svalbard. Journal of Plankton Research 25: 1-20.

LISCHKA S. and HAGEN W. 2016. Seasonal dynamics of mesozooplankton in the Arctic Kongsfjord (Svalbard) during year-round observations from August 1998 to July 1999. Polar Biology, 39: 1859-1878.

LOUGH R.G. and BRoughton E.A. 2007. Development of micro-scale frequency distributions of plankton for inclusion in foraging models of larval fish, results from a Video Plankton Recorder. Journal of Plankton Research 29: 7-17.

NichOLS J.H. and THOMPSON A.B. 1991. Mesh selection of copepodite and nauplius stages of four calanoid copepod species. Journal of Plankton Research 13: 661-671.

PeARCY W.G., GreEnLAW C.F. and Pommeranz T. 1983. Assessment of euphausiids with five nets and a 120-kHz echosounder in fjords of northern Norway. Biological Oceanography 2: $151-177$ 
RICHTER C. 1995. Seasonal changes in the vertical distribution of mesozooplankton in the Greenland Sea Gyre $\left(75^{\circ} \mathrm{N}\right)$ : distribution strategies of calanoid copepods. ICES Journal of Marine Science 52: 533-539.

Sameoto D., Wiebe P., Runge J., Postel L., Dunn J., Miller C. and Coombs S. 2000. Collecting zooplankton. In: R.P. Harris, P.H. Wiebe, J. Lenz, H.R. Skjoldal, M. Huntley (eds) ICES zooplankton methodology manual. Elsevier, Academic Press: 53-81.

Søreide J.E., Hop H., FALK-Petersen S., Gulliksen B. and HANSEN E. 2003. Macrozooplankton communities and environmental variables in the Barents Sea marginal ice zone in late winter and spring. Marine Ecology Progress Series 263: 43-64.

SWANBERG N. and BÅMSTEDT U. 1991. Ctenophora in the Arctic: the abundance, distribution and predatory impact of the cydippid ctenophore Mertensia ovum in the Barents Sea. Polar Research 10: 507-524.

TANDE K.S. 1991. Calanus in North Norwegian fjords and in the Barents Sea. Polar Research 10: 389-407.

Trudnowska E., GŁuchowska M., Beszczynska-Möller A., BŁachowiaK-SAMOŁYK K. and KWAŚNIEWSKI S. 2016. Plankton patchiness in the Polar Front region of the West Spitsbergen Shelf. Marine Ecology Progress Series 560: 1-18.

VANNUCCI M. 1968. Loss of organisms through the meshes. In: D.J. Tranter (ed.): Monographs on Oceanographic Methodology 2: Zooplankton Sampling. UNESCO, Paris: 77-86.

VINOGRADOV M.E. 1997. Some problems of vertical distribution of meso- and macroplankton in the Ocean. In: J.H.S. Blaxter, A.J. Southward, A.V. Gebruk, E.C. Southward and P.A. Tyler (eds) Advances in Marine Biology. Academic Press, San Diego London Boston New York Sydney Tokyo Toronto: 1-92.

Webster C.N., Varpe Ø., FalK-Petersen S., Berge J., StÜBner E. and Brierley A.S. 2015. Moonlit swimming: vertical distributions of macrozooplankton and nekton during the polar night. Polar Biology 38: 75-85.

Weydmann A., Søreide J.E., Kwasniewski S., Leu E., FAlK-Petersen S. and Berge J. 2013. Ice-related seasonality in zooplankton community composition in a high Arctic fjord. Journal of Plankton Research 35: 831-842.

Wiebe P.H., Skjoldal H.R., Postel L., Allison M.D., Groman R.C. and KnUtsen T. 2002. ICES/GLOBEC Sea-Going Zooplankton Workshop for Intercalibration of Plankton Samplers. A compilation of Data, Metadata, and Visual Material. ICES Cooperative Research Report 250: $1-22$.

WIEBE P.H. and BENFIELD M.C. 2003. From the Hensen Net toward four-dimensional biological oceanography. Progress in Oceanography 56: 7-136.

WILLIAMS R. and LINDLEY J.A. 1982. Variability in abundance, vertical distribution and ontogenetic migrations of Thysanoessa longicaudata (Crustacea: Euphausiacea) in the north-eastern Atlantic Ocean. Marine Biology 69: 321-330.

Wold A., Darnis G., Søreide J.E., Leu E., Philippe B., Fortier L., Poulin M., Kattner G., Graeve M. and FALK-PETERSEN S. 2011. Life strategy and diet of Calanus glacialis during the winter-spring transition in Amundsen Gulf, southeast Beaufort Sea (Arctic Ocean). Polar Biology 34: 1929-1946.

Zhukova N.G., Nesterova V.N., Prokopchuk I.P. and Rudneva G.B. 2009. Winter distribution of euphausiids (Euphausiacea) in the Barents Sea (2000-2005). Deep Sea Research II 56: 1959-1967. 